\title{
BAURAN KOMUNIKASI PEMASARAN DALAM MEMASARKAN DESTINASI WISATA ALAM SAAT PANDEMI COVID-19
}

\section{MARKETING MIX OF COMMUNICATION IN NATURE TOURISM DESTINATION MARKETING DURING COVID-19 PANDEMICS}

\author{
Gilang D. Anggoro', Amri Dunan², Karman ${ }^{3 *}$ \\ ${ }^{1,2}$ Ilmu Komunikasi-Universitas Guna Darma, Depok \\ 2,3 Kementerian Komunikasi dan Informatika RI \\ Jl. Medan Merdeka Barat No. 8, Jakarta, Indonesia \\ ${ }^{1}$ gd.anggoro@gmail.com; ${ }^{2}$ amri_dunan@staf.gunadarma.ac.id; ${ }^{3}$ karman@kominfo.go.id \\ Diterima tgl. 22/02/2021 Direvisi tgl. 03/12/2021 Disetujui tgl. 15/12/2021
}

\begin{abstract}
Every tourism industry must practice tourism communication, during pandemics. Good tourism communication helps the industries in marketing their products or services. Hence, they need a strategy to increase success potential and minimize risk one. This study aims to describe the tourism communication strategy during Covid-19 pandemics by adopting the concept of Marketing Mix of Communication. This research method is qualitative with a case study approach. Data are collected by in-depth interviews, observations, and documentation. The results show that their tourism communication strategy is by advertising, personal selling, sales promotion, direct marketing, public relations, and WOM. The management also prioritizes a vital role in delivering information about Covid-19 to maintain tourism, and the content provided can be helpful for tourists.
\end{abstract}

Keywords: nature tourism, communication marketing mix, Pandemics of Covid-19

\section{ABSTRAK}

Setiap industri pariwisata harus mempraktikkan komunikasi pariwisata, termasuk saat pandemi. Komunikasi pariwisata yang baik membantu industri dalam memasarkan produk atau jasanya. Oleh karena itu, diperlukan strategi untuk meningkatkan potensi keberhasilan dan meminimalkan risiko. Penelitian ini bertujuan untuk mendeskripsikan strategi komunikasi pariwisata pada masa pan demi Covid-19 dengan mengadopsi konsep Marketing Mix of Communication. Metode penelitian ini adalah kualitatif dengan pendekatan studi kasus. Pengumpulan data dilakukan dengan wawancara mendalam, observasi, dan dokumentasi. Hasil penelitian menunjukkan bahwa strategi Marketing Mix of Communication pariwisata mereka yaitu dengan iklan, personal selling, sales promotion, direct marketing, public relations, dan WOM. Manajemen juga mengutamakan peran vital dalam penyampaian informasi tentang Covid-19 untuk menjaga pariwisata, dan konten yang diberikan dapat bermanfaat bagi wisatawan.

Kata-kata kunci: pariwisata alam, bauran komunikasi pemasaran, pandemik Covid-19.

\section{PENDAHULUAN}

Pandemi Covid-19 telah memberikan implikasi pada segala sektor, termasuk sektor pariwisata. Di industri pariwisata Indonesia, virus ini mulai memberi dampak pada awal tahun 2020. Media sosial pun saat ini sering digunakan dalam dunia bisnis, pemanfaatan media sosial memudahkan kita dalam mengubah konsep penjualan yang beralih menjadi toko daring. Fenomena ini merupakan cara baru masyarakat dalam berbelanja di era digital. Akun media sosial seperti Facebook dan Twitter. Selain Facebook, Twitter, yang menjadi media sosial yang tumbuh dengan cepat adalah Instagram (Smith \& Anderson, 2018). Dalam waktu kurang dari satu tahun, penggun a akun media sosial ini telah bertambah sebanyak 100 juta pengguna di seluruh dunia. Di Indonesia 
sendiri jumlah pengguna Instagram sebanyak 62 juta lebih, sekitar 51\% wanita memiliki akun Instagram dan pria hanya 49\% (NapoleonCat, 2020).

Wisatawan kerap menjadikan media sosial sebagai media untuk menceritakan aktivitas perjalanannya (Rukmiyati \& Suastini, 2016). Wisatawan atau pelancong dikenal aktif dalam mengunggah foto atau video tentang bagaimana dia berkunjung ke suatu daerah atau wisata yang dia kunjungi. Inilah yang kemudian menjadikan media sosial menjadi media promosi pariwisata meskipun tanpa disadari oleh pengguna media sosial itu sendiri (Hamzah, 2013).

Banyak pengguna media secara aktif mengunggah kegiatan mereka dalam berwisata di media sosial berupa foto dan video. Cara-cara tersebut menjadikan media sosial secara tidak langsung telah menjadikan objek wisata yang sudah dikunjungi menjadi terkenal dan tren serta dapat menarik perhatian di masyarakat. objek wisata yang ada di Luhur Citorek Kabupaten Lebak semakin populer di kalangan masyarakat luas, hal tersebut juga karena pengaruh dari pesan yang diposkan di media sosial seperti Instagram. Cara penggunaan aplikasi yang mudah membuat masyarakat lebih memilih aplikasi Instagram sebagai mempermudah pencarian, karena ada fitur tanda pagar yang tentunya sangat memudahkan mencari visual atau gambar yang diin ginkan, dan penggunaan yang cepat meningkat dapat dijadikan strategi pemasaran yang jitu bagi Industri Wisata Indonesia dalam mempromosikan berbagai keindahan dan budaya yang ada di Indonesia ini. Dari hasil riset sebelumnya dilakukan, peneliti mendapatkan alasan memilih Instagram sebagai salah satu strategi komunikasi pariwisata karena media tersebut hanya berfokus pada gambar dan visual artinya dalam aplikasi tersebut menampilkan bentuk foto dan video yang tepat untuk dijadikan media promosi dan bagaimana strategi komunikasi industri wisata tersebut dalam upaya menangani masalah virus Covid-19 yang sedang melanda seluruh dunia.

Strategi komunikasi pariwisata alam yang dilakukan di suatu daerah menggunakan media sosial merupakan menjadi hal yang menarik karena virus Covid-19 yang sedang menyerang khususnya di Industri wisata perlu dilakukan strategi lain agar devisa negara melalui promosi pariwisatanya dapat terus menjadi penyumbang terbesar di Indonesia. Instagram sering dimanfaatkan untuk industri wisata (Kurniawati, 2017; Munawwaroh \& Lubis, 2018; Satvikadewi \& Hamim, 2018; Umami, 2015). Instagram menonjolkan fitur yang variatif, dan akan sangat membantu peneliti ingin mengetahui strategi komunikasi yang dilakukan Industri Wisata dalam menggunakan akun @gunung_luhur sebagai media promosi pariwisata. Berdasarkan latar belakang di atas masalah yang ingin diteliti peneliti adalah bagaimana strategi komunikasi yang dilakukan Industri wisata yang terdampak Covid-19 dalam menggunakan akun Instagram @ gunung_luhur sebagai media promosi pariwisata daerah lebak? Rumusan masalah dari penelitian ini Bagaimana Strategi komunikasi industri wisata yang terdampak Covid-19 melalui media sosial Instagram akun @ gunung_luhur?. Tujuan penelitian ini untuk mengetahui strategi komunikasi pariwisata Gunung Luhur yang terdampak Covid-19 melalui media sosial Instagram @ gunung_luhur.

Dalam penelitian ini peneliti akan menggunakan teori bauran pemasaran karena pariwisata merupakan subjek yang serta merta memberikan pelayanan dan kebutuhan dari masyarakat. Bentuk strategi komunikasi yang diterapkan oleh Industri wisata Kabupaten Lebak adalah pemasaran jasa. Bauran Pemasaran merupakan alat yang dapat digunakan pemasaran untuk membentuk karakteristik jasa yang dapat ditawarkan kepada masyarakat. Konsep bauran pemasaran antara lain produk, harga, promosi, dan penempatan (Acutt, 2015; Farida \& Tarmizi, 2016; Firmansyah \& Mochklas, 2018; Išoraité, 2016; Todorova, 2015). Menurut penulis, promosi merupakan sebuah proses penyampaian informasi kepada target pasar mengenai hal-hal yang menyangkut produk, harga, tempat produk dijual dengan melakukan persuasif agar target mau melakukan pembelian.

Kegiatan promosi tidak hanya berfungsi sebagai alat komunikasi antara perusahaan dengan konsumen, melainkan juga sebagai alat untuk mempengaruhi konsumen dalam kegiatan pembelian 
atau penggunaan jasa sesuai dengan kebutuhannya. Promosi dalam kegiatan pariwisata disimpulkan sebagai arus informasi satu arah yang dibuat untuk mengarahkan calon wisatawan atau lembaga usaha pariwisata kepada tindakan yang mampu menciptakan pertukaran (jual beli) dalam pemasaran pariwisata. Ini merupakan sebagai upaya dalam memasarkan wisata Gunung Luhur sebagai kota wisata. Saat ini banyak organisasi menyadari bahwa perlunya upaya untuk mengintegrasikan berbagai kegiatan komunikasi pemasaran melalui teknik bauran promosi.

Adapun kegiatan bauran promosi tersebut mencakup: Periklanan, Penjualan personal, Promosi penjualan, Hubungan masyarakat, pemasaran langsung (Suryadana \& Octavia, 2015), pemasaran Word of Mouth atau WOM (Hasan, 2015) termasuk WOM daring (Steffes \& Burgee, 2009). Di era digital seperti ini ada beragam pilihan media yang bisa digunakan seperti televisi, media cetak bahkan media daring. Kebutuhan akan informasi pada saat ini, membuat manusia lebih memilih media yang mudah dan cepat diakses untuk mendapatkan informasi. Bahkan pada faktanya saat ini hampir semua manusia atau masyarakat yang hidup di era digital seperti memiliki alat atau teknologi yang digunakan untuk mengakses informasi seperti telepon cerdas, atau sejenisnya. Maka, komunikator akan sangat dimudahkan dalam hal ini untuk menyampaikan pesan kepada orang banyak. Media daring adalah media berbasis telekomunikasi dan multimedia (komputer dan internet). Termasuk kategori media daring adalah portal, web (termasuk blog dan media sosial seperti Youtube, Instagram, Facebook dan Twitter), radio daring, TV daring, dan surat elektronik (Romli, 2012; Safko, 2010).

Instagram adalah sebuah kelompok aplikasi menggunakan basis internet dan teknologi web.2.0 yang memungkinkan pertukaran dan penciptaan konten oleh pengguna (Kaplan \& Lein, 2010). Media daring mempermudah penggunaan dalam hal interaksi dan adanya partisipasi yang cepat melalui bentuk media sosial. Media sosial adalah platform media yang memfokuskan pada eksistensi pengguna yang memfasilitasi mereka dalam beraktivitas maupun berkolaborasi (Nasrullah, 2015). Oleh karena itu, media sosial dapat dilihat sebagai medium yang menguatkan ikatan sosial. Instagram adalah bentuk dari salah satu media jejaring sosial yang dapat dimanfaatkan sebagai media pemasaran langsung, melalui Instagram produk/jasa dapat ditawarkan dengan mengunggah foto atau video singkat, sehingga para calon konsumen dapat melihat jenisjenis barang/jasa yang ditawarkan. Dalam pemasaran barang yang tidak nyata, dalam hal ini pariwisata, produk pariwisata berupa aspek pelayanan yang memiliki unsur yang tidak nyata. Produk yang dijual dalam industri pariwisata adalah kumpulan produk pariwisata: hotel, taman bermain, ataupun tempat-tempat hiburan lainnya.

\section{METODE PENELITIAN}

Objek dalam penelitian ilmiah ini adalah Strategi komunikasi industri wisata Gunung Luhur yang terdampak Covid-19 melalui media sosial Instagram akun @ gunung_luhur. Subjek penelitian ini dapat berupa orang, tempat, ataupun benda yang diamati dalam penelitian. Subjek dalam penelitian ini adalah pengelola Industri Wisata Gunung Luhur, Admin akun @ gunung_luhur dan Empat akun yang mengikuti Akun Instagram @Gunung_luhur.Lokasi penelitian ini yaitu terletak di Kabupaten Lebak, Desa Citorek Provinsi Banten, Indonesia. Penelitian ini dilakukan secara bertahap dari bulan Januari 2020 hingga September 2020. Pendekatan Penelitian ini menggunakan jenis penelitian kualitatif dengan pendekatan studi kasus. Paradigma yang digunakan di dalam penelitian ini adalah paradigma konstruktivisme. Paradigma konstruktivis adalah pendekat an yang menggunakan pola pikir induktif yaitu berjalan dari yang spesifik menuju umum dan dari yang konkret menuju abstrak (Poerwandi, 2005). Selain itu, pengetahuan dapat digambarkan sebagai hasil konsekuensi dari aktivitas manusia, pengetahuan merupakan konstruksi manusia, tidak pernah 
dipertanggung jawabkan sebagai kebenaran yang tetap tetapi merupakan permasalahan dan selalu berubah (Guba, 1990).

Dalam penelitian ini, peneliti mengumpulkan data dengan wawancara dan observasi. Wawancara. peneliti menggunakan tahap tersebut yaitu dengan bertatap muka langsung antara peneliti sebagai pewawancara dengan informan). Lima informan yang telah peneliti pilih telah sesuai dengan kriteria informan yang dibutuhkan pada penelitian ini. Berikut adalah daftar tabel informan yang telah peneliti wawancarai: Pengelola Wisata Gunung Luhur. Admin Akun @gunung_luhur, dan wisatawan. Observasi (Dalam penelitian ini, peneliti mengobservasi akun Instagram @ gunung_luhur sejak 5 Juli sampai 20 Agustus 2019).

Keabsahan penelitian dengan analisis triangulasi. Triangulasi dilakukan dengan cara membandingkan atau mengecek ulang derajat kepercayaan suatu informasi yang diperoleh dari sumber yang berbeda. Triangulasi yang dipakai oleh peneliti adalah hasil dari akun media sosial @ gunung_luhur yang ada di Kabupaten Lebak dan hasil dari akun-akun yang mengikuti akun @gunung_luhur. Peneliti melakukan Triangulasi metode dengan menggunakan lebih dari satu teknik pengumpulan data untuk mendapatkan yang sama. Triangulasi ini dilakukan untuk memperoleh data mengenai strategi komunikasi industri wisata daerah Kabupaten Lebak dalam promosi pariwisata melalui media sosial Instagram @ gunung_luhur. Triangulasi metode dalam penelitian ini dilakukan dengan membandingkan data hasil wawancara dan observasi yang telah dilaksanakan. Sumber yang dilakukan dengan membandingkan data hasil wawancara dengan hasil observasi yang telah dilakukan.

\section{HASIL DAN PEMBAHASAN}

\subsection{Deskripsi Objek dan Subjek Penelitian}

Pariwisata Gunung Luhur atau yang biasa kita kenal dengan wisata negeri di atas awan dapat digambarkan sebagai berikut. Pariwisata ini merupakan salah satu wisata yang menyajikan panorama bentang alam. Wisata ini berada di wilayah Kampung Ciusul, Desa Citorek, Lebak, Banten. Wilayah Gunung Luhur pada awalnya merupakan sebuah dataran tinggi yang tidak untuk direncanakan sebagai sebuah objek wisata. Namun, dahulu terdapat beberapa kelompok pecinta alam (anak Karang Taruna) selalu mengunjungi tempat tersebut. Karang Taruna tersebut juga sering memperkenalkan objek dataran tinggi kepada masyarakat sekitar. Mereka menggunakan berbagai aplikasi media daring untuk mengabadikan setiap momen di sana dan kemudian menyebarluaskan dataran tinggi tersebut. Penggunaan aplikasi media daring mempunyai pen garuh yang cukup besar, informasi yang dihasilkan oleh media daring memberikan efek yang cukup cepat dan akurat.

Masyarakat daerah setempat pun setuju dan membantu bergotong-royong membuat fasilitas tersebut agar dapat dinikmati oleh masyarakat secara luas nantinya. Pihak Karang Taruna membuat surat izin kepada Dinas Pariwisata Kota Lebak. Perizinan yang diajukan pun penuh dengan pro dan kontra karena tanah dataran tinggi tersebut merupakan tanah taman nasional atau yang biasa kita kenal dengan hutang lindung. Pihak pengelola mengambil langkah untuk tetap merawat hutannya. Sedikit demi sedikit pun Pemerintah mengerti, Pihak Dinas Pariwisata Kota Lebak akhirnya memberikan izin kepada pengelola serta ikut membantu membangun sebuah penginapan sementara untuk para wisatawan yang datang ke sana.

Akun Instagram @gunung_luhur sebagai media strategi komunikasi pariwisata. Akun Instagram @ gunung_luhur memiliki 13.8k pengikut dan sudah membuat pesan sebanyak 224 kiriman pembaruan pada tanggal 30 Agustus 2020 


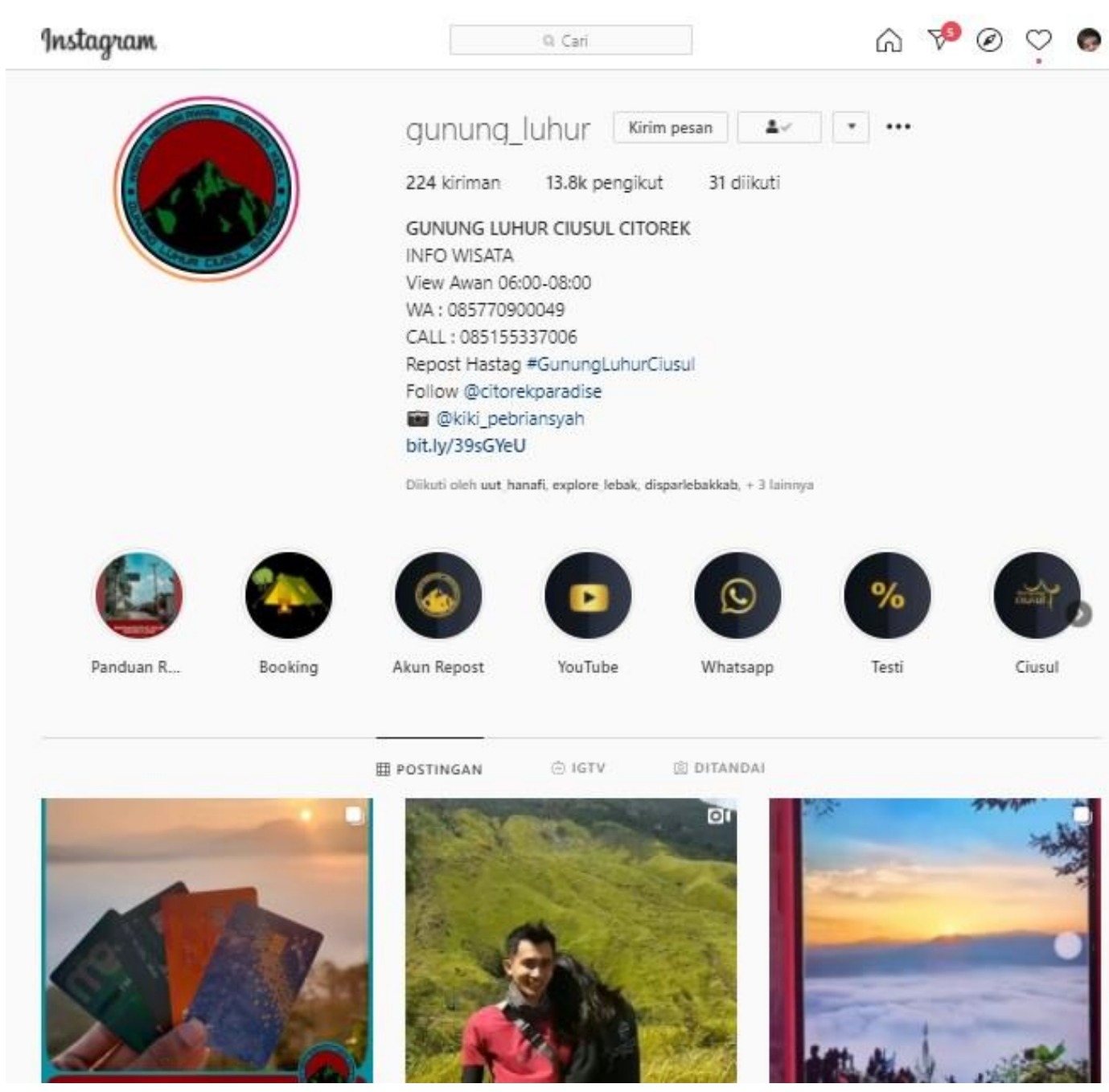

Gambar 1. Akun Instagram Gunung Luhur

Sumber:Instagram @gunung_luhur

Dalam mempromosikan destinasi pariwisata Gunung Luhur di akun Instagram @Gunung_luhur terdapat beberapa konten yang menjelaskan bagaimana program pengelola ataupun aktivitas sosial untuk menjaga kesehatan serta lingkungan pada destinasi wisata terutama pada kondisi covid-19 seperti ini adalah sebagai berikut. Konten promosi destinasi pariwisata. Konten promosi merupakan salah satu konten yang berisi pesan yang diposkan pemandangan destinasi serta penjelasan mengenai objek wisata tentang apa saja yang terdapat di wisata Gunung Luhur. Pengelola menyertakan akun destinasi tersebut agar semakin banyak dan mempermudah akun yang mengikuti akun destinasi sehingga meningkatkan tingkat keterikatan akun Instagram destinasi pariwisata di Gunung Luhur. Pengelola wisata Gunung Luhur membuat akun @ gunung_luhur untuk dapat menyiapkan konten foto atau video yang dapat dimuat di media sosial agar konten media sosial Gunung Luhur dapat tetap produktif dalam memberikan kon ten di media sosial. 


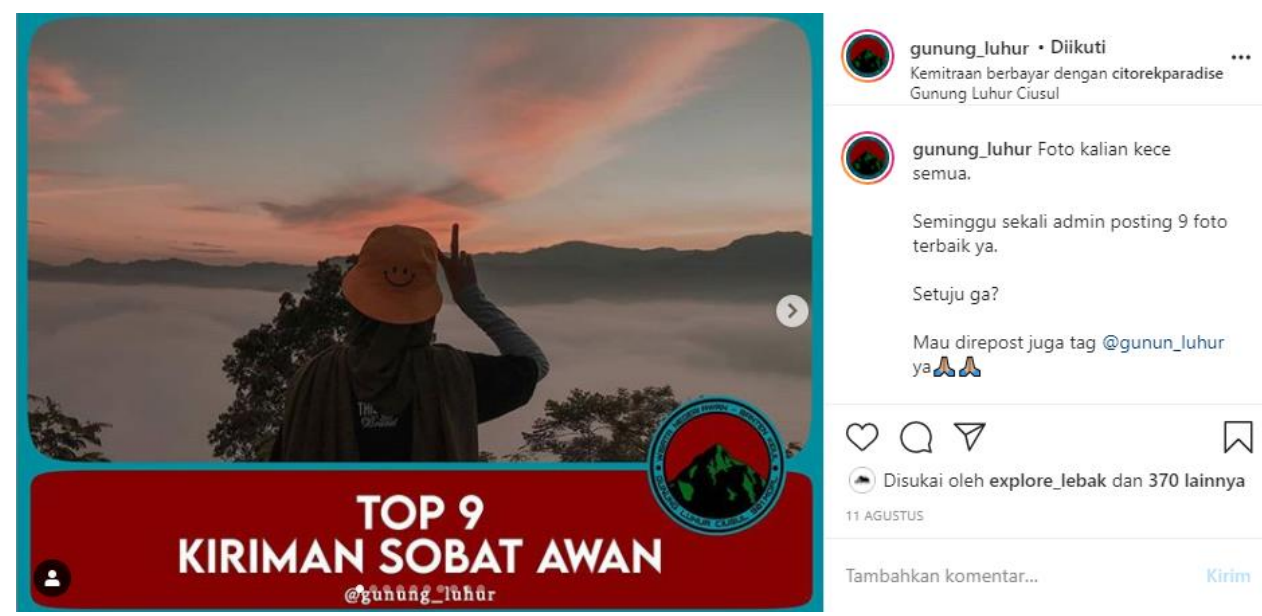

Gambar 2 Pesan Promosi Destinasi @gunung_luhur

Sumber: Instagram @ gunung_luhur

Kedua, Konten Kegiatan Pengelola Pariwisata Gunung Luhur. Konten aktivitas merupakan salah satu peran penting dalam program yang dilakukan oleh pengelola untuk memperkenalkan kepada pengunjung wisata Gunung Luhur. Dari pesan yang dipos akun Instagram @ gunung_luhur membuat masyarakat ataupun wisatawan mengerti dan memahami program yang ingin dilaksanakan oleh pengelola pariwisata Gunung Luhur. Jika terdapat himbauan yang atau seputar informasi yang terjadi di dalam wisata Gunung Luhur dapat langsung tersampaikan dengan baik dan cepat, ini juga yang menjadi kelebihan dari Instagram yang menjadikan alasan bagi pariwisata Gunung Luhur aktif di media sosial Instagram.
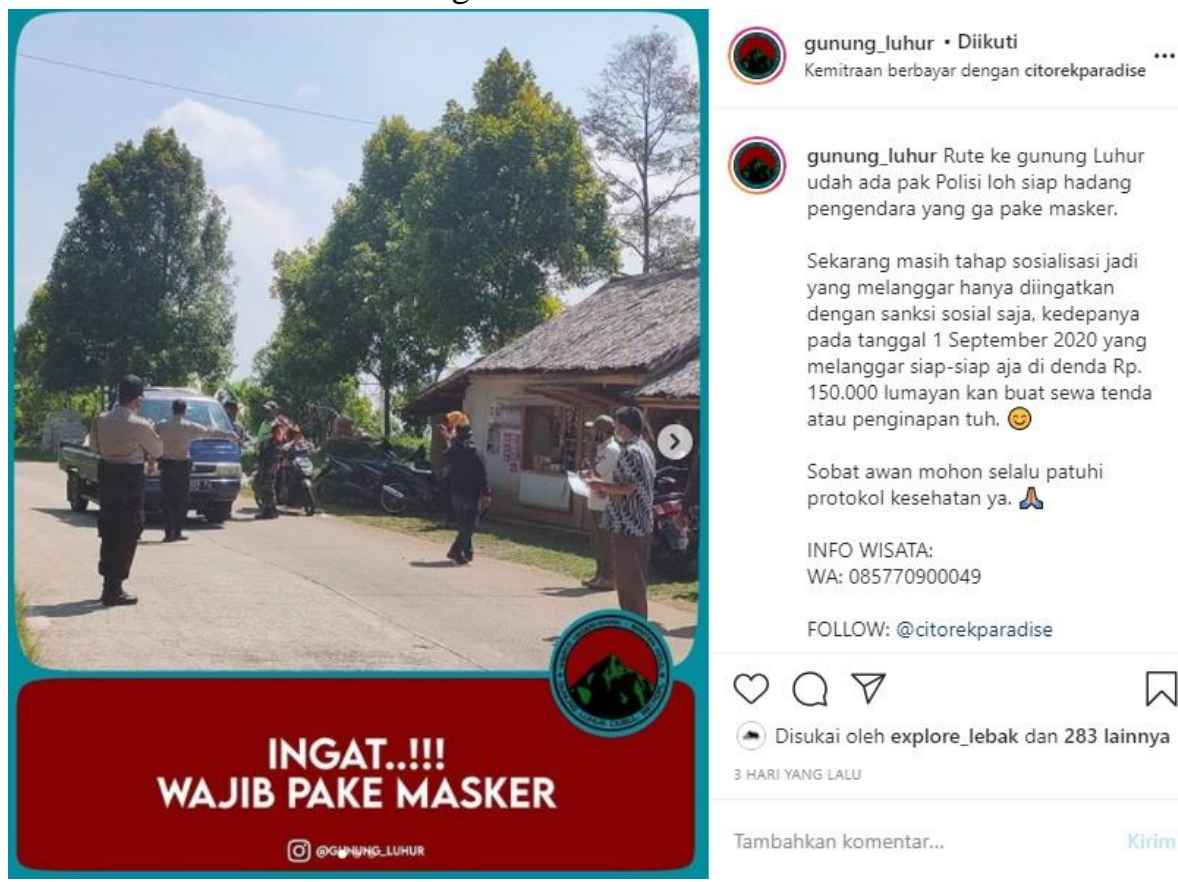

- Disukai oleh explore_lebak dan 283 lainnya 3 HARI YANG LaLU

Gambar 3 Pesan Kegiatan Pariwisata Gunung Luhur

Sumber: Instagram @gunung_luhur

Ketiga, Kegiatan Desa Citorek Gunung Luhur. Kegiatan desa daerah Citorek Gunung Luhur merupakan agenda yang rutin di buat oleh pengelola masing-masing desa daerah Citorek untuk membuat wisatawan meningkat salah satunya yaitu dengan mengadakan kegiatan, kegiatan di desa tersebut membuat wisatawan melihat budaya yang terdapat di desa Citorek. Pengelola pariwisata 
Gunung Luhur memasukkan pesan kegiatan desa sebagai promosi peningkatan wisatawan di desa daerah Citorek Gunung Luhur. Subjek penelitian pada penelitian ini adalah Kepala Pengelola Wisata Gunung Luhur dan Admin Akun Instagram serta tiga akun yang mengikuti Akun Instagram @gunung_luhur. Subjek yang dipilih berdasarkan kriteria tertentu. Komunikasi sangat penting antar individu karena dapat membangun kedekatan atau interaksi begitu pula dengan akun-akun yang mengikuti. Peneliti mengamati dalam proses komunikasi tersebut menghasilkan sebuah strategi komunikasi pariwisata, dalam komunikasi tersebut terdapat cara agar menarik perhatian masyarakat atau akun yang mengikuti untuk berkunjung ke wisata tersebut.

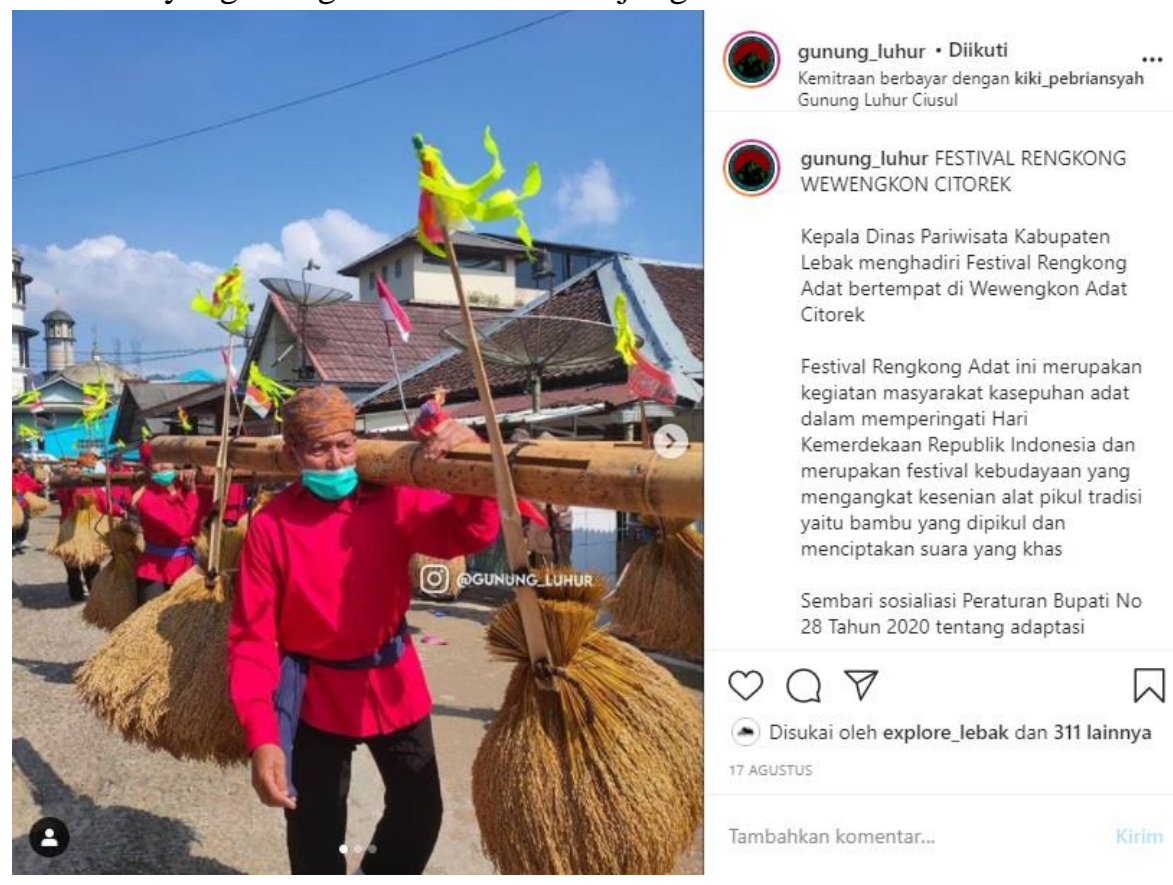

Gambar 4 Pesan Kegiatan Desa Citorek

Sumber: Instagram @ gunung_luhur

\subsection{Peran Instagram Dalam Komunikasi Pariwisata}

Salah satu peran penting dalam fitur Instagram adalah sifatnya yang selalu terkini, pihak pengelola dalam akun Instagram @gunung_luhur selalu memberikan segala informasi yang dibutuhkan oleh wisatawan berupa harga tiket, penyewaan penginapan, tenda dan informasi seputar cuaca serta kondisi akses jalan yang dilalui agar wisatawan aman, dan selama masa pandemi berlangsung pihak pengelola juga selalu mengingatkan kepada pengunjung untuk selalu menggunakan masker dan mencuci tangan sesuai dengan fasilitas yang sudah di sediakan serta himbauan terhadap pelanggaran peraturan protokol kesehatan yang di harapkan wisatawan lebih mudah dan mengerti bagaimana berwisata dengan aman dan nyaman.

Admin akun Instagram @gunung_luhur selalu memprioritaskan akun-akun yang mengikuti mereka untuk mengabadikan setiap momen foto atau video. Dengan mengirim ulang kegiatan yang dilakukan wisatawan diharapkan media sosial dapat menjangkau target konsumen tertentu dan dapat menjangkau khalayak di seluruh dunia. WOM juga dianggap lebih efektif karena informasinya langsung diterima oleh wisatawan. Wisata Gunung Luhur selalu memberikan layan an yang baik agar wisatawan merasa nyaman dan akan datang lagi membawa teman atau kerabatnya. Kemudian wisata Gunung Luhur juga memberikan sebuah Grup percakapan yang berisikan wisatawan mereka agar bisa menyebarkan informasi mengenai Wisata Gunung Luhur. 
Penggunaan Instagram merupakan salah satu dari sekian banyak pengelola menjadikan media tersebut sebagai kunci dari promosi pariwisata, wisata negeri di atas awan yang terdapat di Gunung Luhur menggunakan media sosial Instagram sebagai media utama untuk promosi destinasi pariwisata di daerah Gunung Luhur Citorek, seperti yang di sampaikan oleh Pak Rizal Oki Priono, sebagai pengelola wisata Gunung Luhur (Wawancara Rizal Oki Priono, 12 Agustus 2020). Menurut Pak Rizal Oki Priono Instagram sudah banyak dimanfaatkan atau digunakan oleh masyarakat secara luas dan pada zaman milenial yang merupakan salah satu target promosi pariwisata dari Wisata Gunung Luhur. Banyak pengguna Instagram sebagai pencari informasi ataupun sebagai media pemberi informasi membantu wisata Gunung Luhur dalam m en yampaikan pesan promosi pariwisata Gunung luhur dan Instagram mendapat perhatian banyak oleh sebagian besar masyarakat khususnya masyarakat pada zaman ini yang memulai pencarian destinasi wisata yang bagus atau mencari info karena berbagai fitur yang telah disediakan oleh Instagram. Hal tersebut didukung juga oleh Anggi Gultom selaku wisatawan dan akun yang mengikuti akun @gunung_luhur. Menurut Anggi Gultom selaku wisatawan dan akun-akun yang mengikuti akun Instagram @gunung_luhur menjelaskan bahwa informasi yang diberikan dalam akun Instagram @ gunung_luhur memudahkannya mendapat informasi yang dibutuhkan.

Media daring seperti Instagram menyajikan informasi berupa gambar atau video dengan menggabungkan sebuah keterangan didalamnya yang memudahkan masyarakat lebih mudah memahami isi atau makna informasi yang disajikan tersebut terkhusus lagi pada pandemi sekarang ini yang mengharuskan persiapan lebih untuk berwisata seperti di Gunung Luhur. Pan demi covid19 membuat segalanya menjadi terbatas, masyarakat menjadi lebih sering mencari informasi melalui media daring karena pandemi yang semakin meresahkan masyarakat belakangan ini. Instagram menjadi sasaran masyarakat karena penggunaannya yang mudah dan efektif. Generasi milenial banyak menggunakan media tersebut untuk mendapatkan Informasi yang mereka perlukan dengan mengikuti berita terkait informasi yang mereka butuhkan. Hal ini dijelaskan oleh Admin Akun Instagram, Azizah yang diwawancarai 13 Agustus 2020.

Menurut Azizah Mutiarani, selaku Admin Instagram menjelaskan bahwa pandemi selama pandemi, peningkatan jumlah akun pengikut mengalami perubahan. Pada dasarnya sebelum atau sesudah adanya pandemi keduanya sama-sama mengalami peningkatan, tetapi ketika selama pandemi berlangsung jumlah akun pengikut tidak meningkat secara signifikan berbeda sebelum pandemi covid-19 terjadi. Pandemi covid-19 membuat sejumlah akun pengikut menggunakan fitur Instagram sebagai kunci dalam mencari informasi yang dibutuhkan. Walaupun tidak banyak wisatawan yang bisa berkunjung ke wisata Gunung Luhur mereka juga lebih mudah untuk menggunakan media Instagram sebagai pelengkap informasi yang dibutuhkan dengan adan ya fitur yang tersedia.

Menurut Admin akun Instagram tersebut, memudahkannya penggunaan tagar (\#) membuat masyarakat menjadi lebih mudah dalam mencari informasi yang dibutuhkan. Bukan hanya penggunaan tanda pagar, penggunaan “@” menjadi salah satu alternatif penunjang promosi yang digunakan dalam menggunakan Instagram sebagai media daring.

Menurut Pernyataan Azizah Mutiarani, dalam fitur Instagram “@” mempunyai pengaruh yan g penting. Dalam penggunaannya fungsi “@” adalah menyebut orang yang ditunjuk atau ditandai sebagai nama pengguna untuk melihat apa yang sudah di tandai dalam pesan tersebut. Sehingga secara tidak langsung membuat para akun pengikut yang awalnya tidak mengetahui informasi yang diberikan kemudian menjadi tahu apa informasi yang disajikan dan bahkan bisa menjadi akun pengikut baru untuk akun Instagram @ gunung_luhur jika pengunjung akun tersebut tertarik dengan konten atau pesan pada akun Instagram @ gunung_luhur tersebut. 


\subsection{Komunikasi Bauran Pemasaran Pada Wisata Gunung Luhur}

Bauran pemasaran merupakan sebuah promosi dalam kegiatan pariwisata disimpulkan sebagai arus informasi satu arah yang dibuat untuk mengarahkan calon wisatawan atau kepada tindakan yang mampu menciptakan timbal balik atau yang biasa kita kenal dengan pertukaran. Dalam pemasaran pariwisata, di mana dalam hal ini sebagai upaya dalam memasarkan wisata Gunung Luhur sebagai kota wisata. Saat ini banyak organisasi menyadari bahwa perlunya upaya untuk mengintegrasikan berbagai kegiatan komunikasi pemasaran melalui teknik bauran promosi. Dalam upaya untuk mengintegrasikan kegiatan komunikasi pemasaran melalui teknik bauran kom unikasi melalui beberapa aspek. Untuk lebih dalam memahami teori ini ada elemen yang mendasari teori tersebut. Kita menyadari bahwa periklanan merupakan salah satu komunikasi yang bertujuan untuk mengajak masyarakat khususnya wisatawan agar pembaca dapat segera melakukan sebuah tindakan. Iklan mempunyai makna yang jelas dan terarah sehingga target dapat mengerti dan memahami tujuan dari persuasi yang diberikan oleh pengelola wisata. Media iklan pada umumnya berbentuk cetak seperti poster atau selebaran kertas, surat langsung, iklan luar ruang, majalah.

Zaman yang semakin maju pesat membuat media tradisional menjadi lebih modern salah satu contohnya adalah penggunaan media daring untuk menyampaikan sebuah iklan. Dari hasil pengamatan yang dilakukan oleh peneliti, pengaruh media baru terhadap periklanan mendapat beragam pendapat. Hal ini pun dijelaskan oleh Pengelola Wisata Gunung Luhur. Menurut Bapak Rizal Oki Priono selaku pengelola wisata Gunung Luhur, Instagram merupakan salah satu media yang dijadikan sebagai pusat iklan. Pada objek wisata tersebut, fitur yang di hadirkan Instagram memudahkan pihak pengelola wisata tersebut untuk membuat sebuah iklan yang dapat membuat wisatawan ingin pergi ke wisata tersebut (Wawancara Rizal Oki Priono, 12 Agustus 2020). Pesan yang diposkan adalah pemandangan dan berbagai kebutuhan terkait dengan perkemahan serta penginapan merupakan objek promosi yang disediakan di akun @gunung_luhur.

Penjualan Personal. Penjualan personal merupakan komunikasi yang terjadi antara produsen yang diwakilkan oleh tenaga penjual dengan konsumen potensial yang melibatkan pikiran dan emosi serta berhadapan langsung dengan pembeli. William G. Nickles mendefinisikan penjualan personal adalah interaksi antar individu, saling bertemu muka yang ditunjukkan untuk menciptakan, memperbaiki, menguasai dan mempertahankan hubungan pertukaran yang saling menguntungkan dengan pihak lain (Hermawan, 2012). Wisata Gunung Luhur sudah dilengkapi dengan fasilitas yang cukup memadai untuk menampung wisata lokal, parkiran yang cukup luas dan tempat khusus seperti untuk beribadah untuk mayoritas orang Indonesia yaitu beragam a Islam ada di wisata tersebut. loket tiket pun terbilang cukup layak jika kita hanya merogoh kocek yang terbilang murah untuk menikmati fasilitas di wisata Gunung Luhurini. Pernyataan ini ditegaskan oleh bapak Rizal Oki Priono tuturnya.

Menurut bapak Rizal Oki Priono, selaku pengelola Wisata Gunung Luhur, biaya tiket yang cukup terjangkau menjadi kunci meningkatkan wisatawan lokal agar dapat berkunjung tanpa memikirkan mengeluarkan anggaran yang besar untuk dapat menikmati wisata Gunung Luhur tersebut. Menurutnya, sifat yang diajarkan untuk selalu ingat kepada hal kecil pun merupakan hal penting. Karena mengingat target konsumen adalah menengah ke bawah artinya jumlah pengunjung dari total keseluruhan pada wisata tersebut mengarah kepada wisatawan lokal daerah setempat. Oleh karena itu penetapan harga yang tepat merupakan sebuah kunci wisata tersebut.

Promosi penjualan. Promosi penjualan adalah insentif jangka pendek untuk mendorong uji coba pembelian sebuah produk. Promosi penjualan bisa berupa diskon atau subsidi untuk memberikan insentif bagi para calon wisatawan untuk mengunjungi sebuah destinasi. Promosi penjualan biasanya merupakan sebuah langkah untuk membuat wisatawan tertarik dan ingin mengunjungi wisata tersebut. Pihak pengelola membuat sebuah pilihan terhadap daftar harga yang 
telah dibuatnya dan kemudian membuat harga miring terhadap barang yang sudah ditentukan bila target tercapai (Wawancara Rizal Oki Priono, 12 Agustus 2020)

Menurut Rizal Oki Priono dalam wawancaranya mengatakan bahwa untuk harga tiket tidak ada harga khusus ataupun diskon, tetapi ada penawaran khusus jika wisatawan memilih untuk menyewa sebuah tenda atau penginapan yang berada di wisata tersebut. Harga yang di tawarkan harus memenuhi syarat salah satunya adalah jika wisatawan ingin menyewa minimal lebih dari satu maka harga yang ditawarkan pada harga normal satuannya akan mendapatkan diskon harga spesial jika wisatawan menyewa dua atau lebih. Cara ini terbilang cukup ampuh untuk wisatawan, ban yak wisatawan datang ke tempat wisata bersama teman atau keluarga. Mereka biasanya menyewa lebih dari satu penginapan atau tenda yang disediakan. Sehingga promo tersebut terbilang tepat pada sasaran.

Hubungan Masyarakat. Humas adalah komunikasi eksternal dengan menggunakan simbol dan tindakan simbolis untuk menginformasikan atau mempengaruhi publik dengan menggunakan tulisan, pemasaran, periklanan, publisitas, promosi, dan kegiatan-kegiatan penting (Liliweri, 2014; Ruslan, 2016). Desa Citorek merupakan desa yang kecil di wilayah Kabupaten Lebak, di sana masih banyak sekali budaya luhur yang tertanam asli. Salah satunya, gotong royong. Masyarakat bergotong-royong membangun dan menjaga ekosistem lingkungan agar terjaga kelestariannya. Banyak sekali cara yang dilakukan pihak pengelola agar wisata gunung luhur dapat terus meningkatkan wisatanya, salah satunya adalah dengan studi banding ke wisata lokal lainnya.

Dari apa yang di jelaskan pengelola wisata Gunung Luhur untuk meningkatkan wisata itu sendiri bisa dengan pihak pengelola mempelajari bagaimana strategi wisata lokal daerah lain dalam melayani wisatawan dengan cara yang benar. Salah satunya adalah akhlak, bersikap sopan merupakan dasar dari budaya yang diajarkan oleh suku Jawa sendiri. Kemudian saling tolong menolong, adat dan kebiasaan masyarakat Indonesia mayoritas adalah saling tolong menolong ini merupakan fondasi dasar masyarakat Indonesia. Selain dengan adanya sistem studi banding kegiatan yang diselenggarakan oleh pengelola wisata Gunung Luhur menjadi sorotan yang penting bagi wisatawan untuk belajar dan mengetahui apa saja komunikasi dan informasi yang diperoleh dari kegiatan adat tersebut salah satunya juga di jelaskan oleh pihak pengelola Wisata Gunung Luhur, Rizal Oki Priono.

Pandemi Covid-19 membuat segala sesuatu menjadi terhambat, menurut Rizal Oki Priono selaku pihak pengelola wisata Gunung Luhur, banyak sekali kegiatan yang diadakan pada bulan Agustus, mengingat bulan tersebut merupakan salah satu bulan kemerdekaan bangsa Indonesia. Pihak pengelola menyayangkan berbagai kegiatan yang akan di adakan sebagian batal karena pandemi, sehingga pihak pengelola wisata Gunung Luhur hanya mengadakan perayaan berupa memasang umbul-umbul dan bendera Indonesia selama satu bulan. Pemasaran langsung dalam aktivitas pariwisata secara luas didefinisikan sebagai komunikasi langsung ke wisatawan atau bisnis yang dirancang untuk menghasilkan respons secara langsung, permintaan informasi lanjutan, atau kunjungan ke tempat lain untuk pembelian produk tertentu. Penggunaan surat, telepon, at au internet dirancang untuk mengkomunikasikan secara langsung atau memastikan respons dan dialog dari wisatawan atau calon wisatawan tertentu adalah salah satu sisi dari model pemasaran langsung. Penggunaan media sosial memang sangat efektif bisa digunakan dengan cara yang tepat.

Rizal Oki Priono dalam wawancaranya (Wawancara Rizal Oki Priono, 12 Agustus 2020), telepon seluler merupakan alat yang penting digunakan pada zaman ini. Pihak pengelola memanfaatkan teknologi yang modern untuk memberikan sebuah informasi terbaru tentang bagaimana keadaan wisata pada satu waktu yang sama. Dikala pandemi berlangsung, wisata Gunung Luhur tidak diperbolehkan beroperasi sesuai himbauan pemerintah. Dengan adanya komunikasi langsung, wisatawan dapat dengan mudah mengerti keadaan wisata pada satu waktu 
tertentu. Pemasaran WOM adalah pemasaran dari orang ke orang atau satu komunitas ke komunitas lainnya di desain secara daring maupun luring agar mau berkunjung ke suatu destinasi wisata (Hasan, 2015). Komunikasi ini biasanya terjadi ketika pelanggan merasakan sebuah produk itu baik atau tidak.

Demikian halnya dalam sektor pariwisata, di mana wisatawan akan memberitahu kerabatkerabatnya tentang sesuatu yang menarik ataupun kurang menarik ketika berkunjung ke suatu destinasi wisata. Peran teman terhadap sebuah informasi cukup mudah diterima dan sering sekali dijadikan acuan dalam memilih keputusan. Sebagai contoh salah satu narasumber peneliti menjelaskan hal berikut: "Saya tahunya dari teman-teman saya yang mengajak ingin berlibur ke wisata ini." (Wawancara Ahmad, 13 Agustus 2020). Menurut salah seorang pengikut akun Instagram, informasi yang di dapatnya melalui teman atau kerabatnya merupakan salah satu pilih an yang membuatnya mengambil keputusan. Komunikasi itu terjadi karena adanya informasi yang menarik dari sebuah pesan yang diberikan kepada wisatawan kemudian menghasilkan sebuah umpan balik dan menghasilkan sebuah keputusan.

\subsection{Diskusi}

Konsep baru tentang Model Bauran Pemasaran ini merupakan model yang terbilang simpel, karena mengutamakan komunikasi secara penuh dengan beberapa faktor seperti Periklanan, Promosi Penjualan, Penjualan Personal, Hubungan Masyarakat, Pemasaran Langsung, WOM sert a fokus pada upaya membangun hubungan dan pemahaman bersama, bukan upaya untuk memersuasi dan juga usaha untuk menutupi unsur-unsur negatif dalam industri wisata tersebut.

Berbicara mengenai bauran pemasaran, maka tentu akan membahas mengenai komunikasi dengan media daring karena pola bauran pemasaran berkembang dengan pesat seiring perkembangan jaringan internet saat ini, karena teori bauran pemasaran terbantu dengan fasilitas jaringan internet tersebut. Internet didefinisikan sebagai interkoneksi pola atau sistem yang dapat mengacu pada hubungan antara jaringan dan jaringan, atau banyak jaringan dari komputer. Penggunaan media sosial dan aplikasi merupakan akses jaringan internet karena di anggap sangat mudah, praktis dan cepat.

Dalam aspek periklanan, media Instagram merupakan media yang paling penting, media Instagram dapat memberikan sebuah informasi melalui sebuah objek gambar ataupun video kepada khalayak luas tanpa batas. Akun @ gunung_luhur merupakan media sosial yang di buat oleh pihak pengelola Wisata Gunung Luhur sebagai media komunikasi yang bersifat dua arah untuk dapat mengubah perilaku pengelola wisata dan akun-akun yang mengikuti pengikut. Akun @gunung_luhur membuat hubungan informasi yang ingin disampaikan oleh pihak pengelola pariwisata dengan akun-akun yang mengikuti tersampaikan secara luas dan terjalin dengan baik.

Promosi penjualan yang ditawarkan oleh pengelola pariwisata sangat bergantung pada internet saat ini, dengan adanya internet pengelola dapat dengan mudah memberikan informasi seputar harga dan biaya yang diperlukan oleh konsumen di wisata tersebut. Karena internet adalah media yang sangat membantu dalam menyebarluaskan informasi dalam era globalisasi seperti saat ini. Kehadiran internet yang telah berkembang menjadi media daring telah mengubah cara masyarakat berkomunikasi. Wisata Gunung Luhur membuat konten yang rapi dan kreatif dengan memudahkan akun-akun yang mengikuti untuk mendapatkan info tentang promosi budaya, daftar harga, kegiatan dan informasi destinasi pariwisata yang ingin dikunjungi.

Wisata Gunung Luhur pun melakukan Penjualan Personal melalui media Instagram dengan memberikan sebuah informasi mengenai harga tiket berkunjung ke wisata tersebut, Akun tersebut juga memaparkan transportasi atau akses yang tersedia jika ingin ke sana. Selain menggunakan beragam media daring, Gunung Luhur pun menggunakan pemasaran langsung melalui media 
telepon yang tersedia dalam 24 jam. Mengenai berbagai informasi yang dibutuhkan juga dapat dicari dengan menghubungkan admin yang tersedia pada kontak Gunung Luhur. Dalam pencapaiannya yang sekarang, Wisata Gunung Luhur tidak terlepas dari pembelajaran tentang wisata lainnya yang dijadikan sebagai objek contoh wisata tersebut. Hubungan masyarakat yang terjadi di Wisata Gunung Luhur berupa bagaimana desa tersebut menerapkan sistem wisata yang sudah ada sebelumnya sebagai contoh kemudian dikembangkan lagi oleh pemilik wisata Gunung Luhur supaya tercipta wisata yang aman dan nyaman.

Dalam proses penyampaian informasi pula. Akun Instagram Wisata Gunung Luhur menggunakan sistem word of mouth atau yang biasa kita kenal dengan sistem dari WOM, informasi yang di sajikan oleh akun @ gunung_luhur biasanya berupa media gambar dan video yang nantinya setiap media tersebut menghasilkan tontonan yang bersifat berantai. Akun Instagram @gunung_luhur pun saling terhubung karena fitur yang di berikan oleh Instagram seperti tanda pagar khusus seperti \#gunung_luhur dan arroba yang membantu menyebarkan informasi lebih luas sehingga memudahkan masyarakat yang sedang mencari informasi yang belum didapatkan melalui media lain. Akun @gunung_luhur juga menjaga citra yang baik sebagai media sosial yang mengedepankan informasi himbauan resmi dari pemerintah di kala pandemi Covid-19.

\section{PENUTUP}

Pemilihan dan pemanfaatan Instagram sebagai media promosi pemasaran daring, terdapat beberapa keterkaitan antara fitur-fitur yang dapat dimanfaatkan dengan pemilihan media yang tepat untuk wisata Gunung Luhur. Fitur yang dimanfaatkan oleh pihak pengelola wisata Gunung Luhur dalam setiap komponen bauran komunikasi pemasaran. Periklanan. Instagram merupakan salah satu media yang dijadikan sebagai pusat iklan. Pada objek wisata tersebut, fitur yang dihadirkan Instagram memudahkan pihak pengelola wisata tersebut untuk membuat sebuah iklan yang dapat membuat wisatawan ingin pergi ke wisata tersebut. Pesan yang diposkan berisi pemandangan dan berbagai kebutuhan camping serta penginapan merupakan objek promosi yang disediakan di akun @ gunung_luhur.

Pertama, penjualan langsung. Biaya tiket yang cukup terjangkau menjadi kunci meningkatkan wisatawan lokal agar dapat berkunjung tanpa memikirkan mengeluarkan anggaran yang besar untuk dapat menikmati wisata Gunung Luhur. Kedua, Promosi Penjualan. Harga yang ditawarkan harus memenuhi syarat salah satunya adalah jika wisatawan ingin menyewa minimal lebih dari satu maka harga yang ditawarkan pada harga normal satuannya akan mendapatkan diskon harga spesial jika wisatawan menyewa dua atau lebih. Cara ini terbilang cukup ampuh untuk wisatawan, ban yak wisatawan datang ke tempat wisata bersama teman atau keluarga.

Ketiga, hubungan masyarakat. Sistem studi banding kegiatan yang diselenggarakan oleh pengelola wisata Gunung Luhur menjadi sorotan yang penting bagi wisatawan untuk belajar dan mengetahui apa saja komunikasi dan informasi yang diperoleh dari kegiatan adat tersebut. Keempat, Pemasaran Langsung. Telepon seluler merupakan alat yang penting digunakan pada zaman ini. Pihak pengelola memanfaatkan teknologi yang modern untuk memberikan sebuah informasi terbaru tentang bagaimana keadaan wisata pada satu waktu yang sama. Di kala pandemi berlangsung, wisata Gunung Luhur tidak diperbolehkan beroperasi sesuai himbau an pemerintah.

Dengan adanya komunikasi langsung, wisatawan dapat dengan mudah mengerti keadaan wisata pada satu waktu tertentu. Kelima, word of mouth. Melalui teman atau kerabatnya merupakan salah satu pilihan yang membuatnya mengambil keputusan. Komunikasi itu terjadi karena adan ya informasi yang menarik dari sebuah pesan yang diberikan kepada wisatawan kemudian menghasilkan sebuah umpan balik dan menghasilkan sebuah keputusan. akibatnya, Ahmad yang 
sama sekali belum pernah datang ke wisata Gunung Luhur dapat tertarik untung berkunjung ke wisata tersebut.

Instagram juga memberikan manfaat yang banyak, sebagai berikut. Instagram sebagai media yang mendukung wisata Gunung Luhur dalam memperkenalkan keunggulan destinasi pariwisatanya dengan fitur yang diberikan oleh Instagram seperti lebih memberikan konten visual sangat mendukung untuk sektor pariwisata karena dengan visual seperti foto atau video yang menarik dan segar membuat masyarakat menjadi tertarik, apalagi dengan di berikannya konten konten selain promosi destinasi pariwisata seperti kegiatan dinas pariwisata, program yang di lakukan oleh pengelola wisata, kegiatan yang diadakan oleh pengelola desa setempat maupun pihak pengelola membuat konten dari @ gunung_luhur menjadi segar dan selalu menarik. Bagi penelitian berikutnya diharapkan mampu melakukan penelitian lebih lanjut dan lebih efisien dalam meneliti penggunaan aplikasi sebagai media komunikasi.

\section{Ucapan Terima kasih}

Penulis perlu menyampaikan ucapan terima kasih kepada mereka yang telah membantu dalam penelitian ini. Terima kasih juga untuk pengelola jurnal studi komunikasi dan media telah membantu penerbitan naskah ini.

\section{DAFTAR PUSTAKA}

Acutt, M. (2015). Marketing Mix Definition - 4Ps \& 7Ps of the Marketing Mix. In Mark Acutt \& Patrick Кио.

Farida, I., \& Tarmizi, A. (2016). Analisis Pengaruh Bauran Pemasaran 7p Terhadap Kepuasan Pelanggan Pengguna Gojek Online. Jurnal Riset Manajemen Dan Bisnis (JRMB) Fakultas Ekonomi UNIAT. https://doi.org/10.36226/jrmb.v1i1.8

Firmansyah, A., \& Mochklas, M. (2018). Analisa Strategi Produk, Harga, Promosi Dan Tempat Terhadap Kepuasan Pelanggan Warung Giras Di Surabaya. Jurnal Eksekutif, 15(1), 281-295.

Guba, E. (1990). The Paradigm Dialog. Sage Publication Ltd.

Hamzah, Y. I. (2013). Potensi Media Sosial Sebagai Sarana Promosi Interaktif Bagi Pariwisata Indonesia. Jurnal Kepariwisataan Indonesia, 8(3), 1-9.

Hasan, A. (2015). Tourism Marketing. CAPS.

Hermawan, A. (2012). Komunikasi Pemasaran. Erlangga.

Išoraite, M. (2016). Marketing Mix Theoretical Aspects. International Journal of Research GRANTHAALAYAH. https://doi.org/10.29121/granthaalayah.v4.i6.2016.2633

Kaplan, A., \& Lein, H. M. (2010). User of The World, Unite! The Challenges and Opportunities Of Social Media. Business Horizons, 53(1), 59-68. https://doi.org/https://doi.org/10.1016/j.bushor.2009.09.003

Kurniawati, W. D. N. (2017). Pemanfaatan Instagram Oleh Komunitas Wisata Grobogan Dalam Mempromosikan Potensi Pariwisata Daerah. Komuniti: Jurnal Komunikasi Dan Teknologi Informasi, $\operatorname{VIII}(2), 127-143$. https://doi.org/10.23917/komuniti.v8i5.2943

Liliweri, A. (2014). Sosiologi \& Komunikasi Organisasi. Bumi Aksara.

Munawwaroh, P. R., \& Lubis, E. E. (2018). Pengaruh Terpaan Media Pada Akun Instagram @ Ex ploresiak Terhadap Minat Kunjungan Wisata Ke Siak Sri Indrapura. Jurnal Online Mahasiswa Fakultas Ilmu Sosial Dan Ilmu Politik Universitas Riau, 5(1), 1-13.

NapoleonCat. (2020). Instagram users in Indonesia. https://napoleoncat.com/stats/instagram-users-inindonesia/2020/04

Nasrullah, R. (2015). Media Sosial Perspektif Komunikasi, Budaya, dan Sosioteknologi. Simbiosa Rekatama Media.

Poerwandi, E. K. (2005). Pendekatan Kualitatif dalam Penelitian Psikologi. In Lembaga Pengembangan Sarana Pengukuran dan Pendidikan Psikologi Fakultas Psikologi UI.LPSP3.

Romli, A. S. M. (2012). Jurnalistik Online: Panduan Mengelola Media Online. In Jurnalistik Online Panduan Mengelola Media Online. Nuansa Cendikia.

Rukmiyati, N. M. S., \& Suastini, N. M. (2016). Dampak Media Sosial Terhadap Perilaku Wisatawan. Conference on Management and Behavioral Studies.

Ruslan, R. (2016). Manajemen Public Relations dan Komunikasi. In Manajemen Public Relations \& Media Komunikasi (13th ed.). Raja Grafindo Persada. 
Safko, L. (2010). The Social Media Bible: Tactics, Tools, and Strategies for Business Success. In Buku (2nd ed.). John Wiley \& Sons, Inc.

Satvikadewi, A. A. I. P., \& Hamim, H. (2018). Pemanfaatan Media Sosial sebagai Strategi Komunikasi untuk Mempromosikan Potensi Lokal Wisata Pulau Bawean. Seminar Hasil Penelitian Dan Pengabdian Masyarakat, 1(1), 102-120. https://simlitabmas.untag-sby.ac.id/index.php/sehasil/article/view/1855/0

Smith, A., \& Anderson, M. (2018, March 1). Social Media Use in 2018. Pew Research. https://www.pewresearch.org/internet/2018/03/01/social-media-use-in-2018/

Steffes, E. M., \& Burgee, L. E. (2009). Social ties and online word of mouth. Internet Rese arch, 19(1), 4259. https://doi.org/10.1108/10662240910927812

Suryadana, L., \& Octavia, V. (2015). Pengantar Pemasaran Pariwisata. Alfabeta.

Todorova, G. (2015). Marketing communication mix. Trakia Journal of Sciences, 13(Supl1.1), 368-374,. https://doi.org/10.15547/tjs.2015.s.01.063

Umami, Z. (2015). Social Strategy Pada Media Sosial Untuk Promosi Pariwisata Daerah Istimewa Yogyakarta. INTERAKSI: Jurnal Ilmu Komunikasi, 4(2), 195-201. https://doi.org/10.14710/interaksi,4,2,195-201 